\title{
GPBP1L1 wt Allele
}

National Cancer Institute

\section{Source}

National Cancer Institute. GPBP1L1 wt Allele. NCI Thesaurus. Code C101467.

Human GPBP1L1 wild-type allele is located in the vicinity of 1p34.1 and is approximately $61 \mathrm{~kb}$ in leng th. This allele, which encodes vasculin-like protein 1, may play a role in the regulation of transcription. 